\title{
HOW THE \\ CLASSICS MADE \\ SHAKESPEARE \\ $B$
}


ALSO BY JONATHAN BATE

Shakespeare and the English Romantic Imagination

Shakespearean Constitutions: Politics, Theatre, Criticism 1730-1830

Romantic Ecology: Wordsworth and the Environmental Tradition

Shakespeare and Ovid

The Genius of Shakespeare

The Song of the Earth

John Clare: A Biography

Soul of the Age: A Biography of the Mind of William Shakespeare

English Literature: A Very Short Introduction

Shakespeare: Staging the World (with Dora Thornton)

Ted Hughes: The Unauthorised Life

AS EDITOR

Charles Lamb: Elia and the Last Essays of Elia

The Romantics on Shakespeare

The Arden Shakespeare: Titus Andronicus

Shakespeare: An Illustrated Stage History (with Russell Jackson)

John Clare: Selected Poems

The RSC Shakespeare: Complete Works (with Eric Rasmussen)

The RSC Shakespeare: Individual Works (with Eric Rasmussen, 36 volumes)

The Public Value of the Humanities

The RSC Shakespeare: Collaborative Plays by Shakespeare and

Others (coeditor)

Worcester: Portrait of an Oxford College (with Jessica Goodman)

Stressed Unstressed: Classic Poems to Ease the Mind (coeditor)

INTRODUCTIONS

Titus: A Film by Julie Taymor

Andrew Marvell: The Complete Poems (Penguin Classics)

The Tempest: A Film by Julie Taymor

The Folio Poets: Lord Byron

CREATIVE WORKS

The Cure for Love (novel)

Being Shakespeare (a one-man play for Simon Callow)

The Shepherd's Hut (poems) 


\section{HOW THE \\ CLASSICS MADE \\ SHAKESPEARE

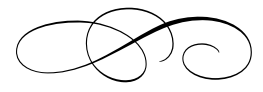 \\ Jonathan Bate}

PRINCETON UNIVERSITY PRESS

PRINCETON AND OXFORD 
Copyright (C) 2019 by Princeton University Press

This book is published as part of the E. H. Gombrich lecture series, cosponsored by the Warburg Institute and Princeton University Press. The lectures upon which this book is based were delivered in October 2013.

Published by Princeton University Press

41 William Street, Princeton, New Jersey 08540

6 Oxford Street, Woodstock, Oxfordshire OX20 1TR

press.princeton.edu

All Rights Reserved

LCCN: 2018957530

ISBN: 9780691161600

British Library Cataloging-in-Publication Data is available

Editorial: Ben Tate, Hannah Paul, and Charlie Allen

Production Editorial: Natalie Baan

Text and Jacket Design: Leslie Flis

Production: Erin Suydam

Publicity: Jodi Price and Katie Lewis

Copyeditor: Hank Southgate

Jacket image: Titian, Venus and Adonis, c. 1555, oil on canvas. Courtesy of Shutterstock

This book has been composed in Minion and Trajan

Printed on acid-free paper. $\infty$

Printed in the United States of America

$\begin{array}{llllllllll}10 & 9 & 8 & 7 & 6 & 5 & 4 & 3 & 2 & 1\end{array}$ 